Keywords: $D W P F$

Glass

Sludge Batch 4

Sludge Batch 5

Retention: Permanent

\title{
Analysis of Sludge Batch 4 (Macrobatch 5) for Canister S02902 and Sludge Batch 5 (Macrobatch 6) for Canister S03317 DWPF Pour Stream Glass Samples
}

M.M. Reigel

N.E. Bibler

September 2010

Savannah River National Laboratory Savannah River Nuclear Solutions Aiken, SC 29808

Prepared for the U.S. Department of Energy under contract number DE-AC09-08SR22470.

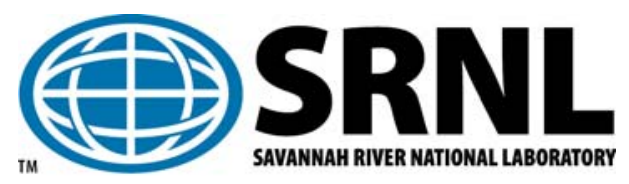


SRNL-STI-2010-00435

Revision 0

\section{DISCLAIMER}

This work was prepared under an agreement with and funded by the U.S. Government. Neither the U.S. Government or its employees, nor any of its contractors, subcontractors or their employees, makes any express or implied:

1. warranty or assumes any legal liability for the accuracy, completeness, or for the use or results of such use of any information, product, or process disclosed; or

2. representation that such use or results of such use would not infringe privately owned rights; or

3. endorsement or recommendation of any specifically identified commercial product, process, or service.

Any views and opinions of authors expressed in this work do not necessarily state or reflect those of the United States Government, or its contractors, or subcontractors.

\section{Printed in the United States of America \\ Prepared for \\ U.S. Department of Energy}




\section{REVIEWS AND APPROVALS}

AUTHORS:

M.M. Reigel, Engineering Process Development

Date

N.E. Bibler, Process Technology Programs

Date

TECHNICAL REVIEW:

D.K. Peeler, Process Technology Programs

Date

APPROVAL:

C.C. Herman, Manager

Date

Process Technology Programs

S.L. Marra, Manager

Date

Environmental \& Chemical Process Technology Research Programs

J.E. Occhipinti, Manager

Date

Waste Solidification Engineering 


\section{EXECUTIVE SUMMARY}

The Defense Waste Processing Facility (DWPF) began processing Sludge Batch 4 (SB4), Macrobatch 5 (MB5) on May 29, 2007. Sludge Batch 4 was a blend of the heel of Tank 40 from Sludge Batch 3 (SB3) and SB4 material qualified in Tank 51. On November 28, 2008, DWPF began processing Sludge Batch 5 (SB5) from Tank 40 which is a blend of the heel of Tank 40 from SB4, SB5 material qualified in Tank 51 and $\mathrm{H}-$ Canyon $\mathrm{Pu}$ and $\mathrm{Np}$ transfers. SB4 was processed using Frit 510 and SB5 used Frit 418.

During processing of each sludge batch, the DWPF is required to take at least one glass sample to meet the objectives of the Glass Product Control Program and to complete the necessary Production Records so that the final glass product may be disposed of at a Federal Repository. During the processing of SB4 and SB5, glass samples were obtained during the pouring of canisters S02902 and S03317, respectively. The samples were transferred to the Savannah River National Laboratory (SRNL) where they were analyzed (durability, chemical and radionuclide composition). The following observations and conclusions are drawn from the analytical results provided in this report:

- The sum of the oxides for the chemical composition of both the SB4 and SB5 pour stream glasses is within the Product Composition Control System (PCCS) acceptance limits $(95 \leq$ sum of oxides $\leq 105)$.

- The calculated Sludge Dilution Factor (SDF) for SB4 is 2.52. The measured radionuclide content is in good agreement with the calculated values from the dried sludge results from the SB4 Waste Acceptance Production Specification (WAPS) sample (References 1 and 19).

- The calculated SDF for SB5 is 2.60. The measured radionuclide content is in good agreement with the calculated values from the dried sludge results from the SB5 WAPS sample (References 2 and 20).

- Scanning Electron Microscopy (SEM) analysis shows there are noble metal inclusions, primarily ruthenium, present in both pour stream samples.

- The Product Consistency Test (PCT) results show that the SB4 pour stream glass meets the waste acceptance criteria for durability with a normalized boron release of $0.67 \mathrm{~g} / \mathrm{L}$ which is an order of magnitude lower than the Environmental Assessment (EA) glass.

- The PCT results show that the SB5 pour stream glass meets the waste acceptance criteria for durability with a normalized boron release of $0.72 \mathrm{~g} /$ which is an order of magnitude lower than the EA glass.

- The density of the SB4 glass is $2.5 \mathrm{~g} / \mathrm{cm}^{3}$.

- The density of the SB5 glass is $2.6 \mathrm{~g} / \mathrm{cm}^{3}$. 


\section{TABLE OF CONTENTS}



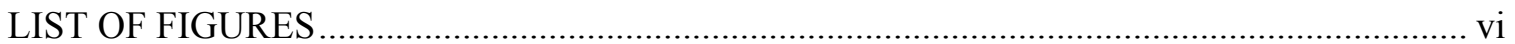

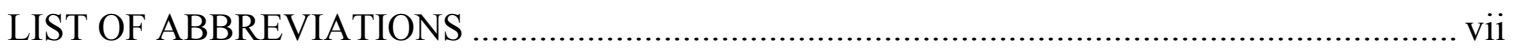

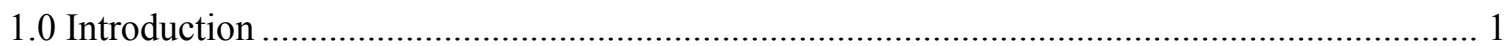

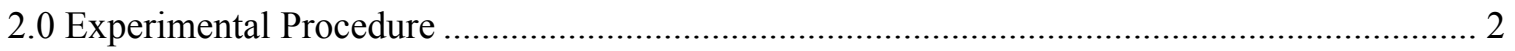

2.1 Visual Examination, Extraction, and Washing ................................................................ 2

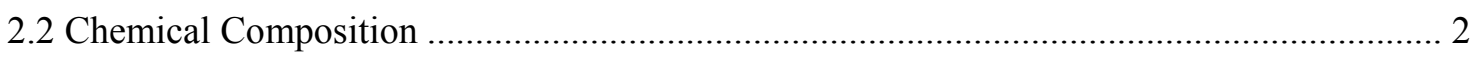

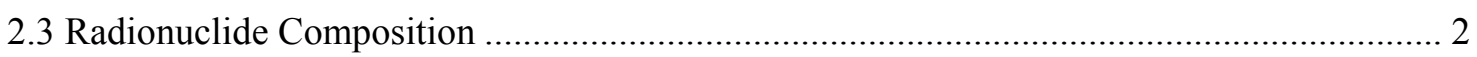

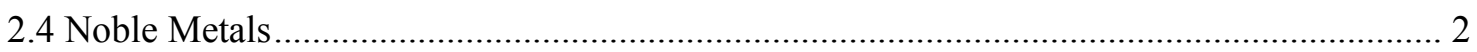

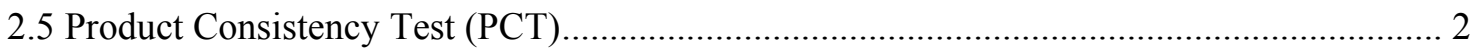

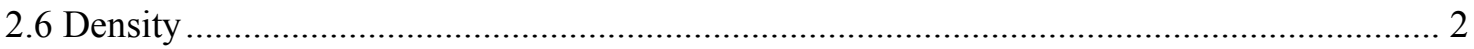



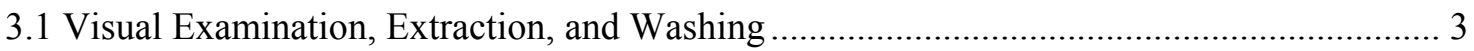

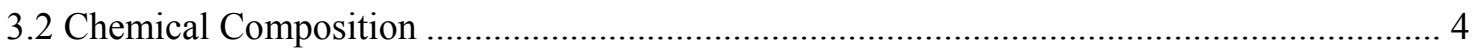

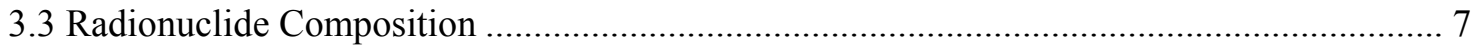



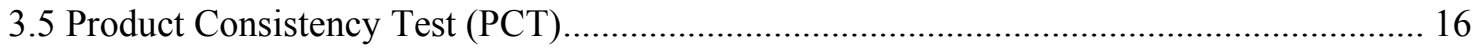

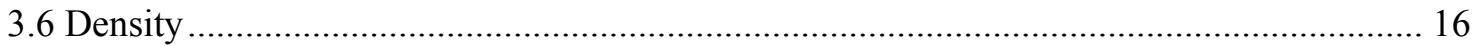



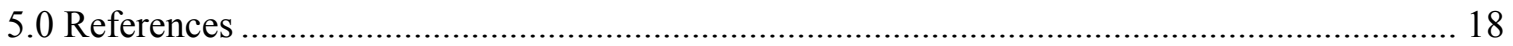




\section{LIST OF TABLES}

Table 1-1. DWPF Pour Stream Glass Sample Data. ..................................................................... 1

Table 3-1. Measured and Published Values of Analytical Reference Glass - 1 (ARG-1)............. 4

Table 3-2. Oxide Composition of SB4 Glass Pour Stream Sample (Canister S02902). ................ 5

Table 3-3. Oxide Composition of SB5 Glass Pour Stream Sample (Canister S03317)................. 6

Table 3-4. Calculation of the Sludge Dilution Factor (SDF) for SB4 Pour Stream Glass. ............. 7

Table 3-5. Calculation of the Sludge Dilution Factor (SDF) for SB5 Pour Stream Glass. ............. 7

Table 3-6. Reportable Radionuclide Content of SB4 Pour Stream Glass. ...................................... 8

Table 3-7. Reportable Radionuclide Content of SB5 Pour Stream Glass. .................................... 9

Table 3-8. Noble Metal Concentration in the SB4 Glass Pour Stream Sample............................ 10

Table 3-9. Noble Metal Concentration in the SB5 Glass our Stream Sample............................... 10

Table 3-10. Normalized PCT Results for SB4 and SB5 Pour Stream Glasses............................ 16

\section{LIST OF FIGURES}

Figure 3-1. DWPF Pour Stream Glass Samples a) SB4 from Canister S02902 and b) SB5 from Canister S03317 As Received By SRNL. ....................................................................... 3

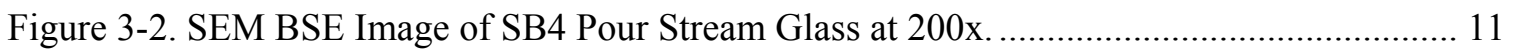

Figure 3-3. SEM Backscatter image of SB4 Pour Stream Glass at 1220x................................ 11

Figure 3-4. EDS Spectra of Spot 5 in Figure 3-3 for SB4 Pour Stream Glass, Indicating the



Figure 3-5. EDS Spectra of Spot 6 in Figure 3-3 for SB4 Pour Stream Glass. ............................ 12

Figure 3-6. SEM BSE Image of SB5 Pour Stream Glass at 220x.......................................... 13

Figure 3-7. SEM BSE Image of SB5 Pour Stream Glass at 714x.......................................... 14

Figure 3-8. EDS Spectra of Spot 1 in Figure 3-7 for SB5 Pour Stream Glass. ............................. 14

Figure 3-9. EDS Spectra of Spot 2 in Figure 3-7 for SB5 Pour Stream Glass Indicating the Presence of Ru Noble Metal Inclusions. ........................................................................... 15

Figure 3-10. EDS Spectra of Spot 3 in Figure 3-7 for SB5 Pour Stream Glass.......................... 15 


\section{LIST OF ABBREVIATIONS}

\begin{tabular}{|c|c|}
\hline $\mathrm{AD}$ & Analytical Development \\
\hline ARG & Analytical Reference Glass \\
\hline ARM & Approved Reference Material \\
\hline ASP & Analytical Study Plan \\
\hline ASTM & American Society for Testing and Materials \\
\hline BSE & Backscattered Electron \\
\hline $\mathrm{Ci}$ & Curie \\
\hline $\mathrm{CPC}$ & Chemical Processing Cell \\
\hline DWPF & Defense Waste Processing Facility \\
\hline EA & Environmental Assessment \\
\hline EDS & Energy Dispersive Spectroscopy \\
\hline $\mathrm{g}$ & gram \\
\hline ICP-ES & Inductively Coupled Plasma - (atomic) Emission Spectroscopy \\
\hline ICP-MS & Inductively Coupled Plasma - Mass Spectrometry \\
\hline $\mathrm{kg}$ & kilogram \\
\hline $\mathrm{L}$ & Liter \\
\hline MB & Macrobatch \\
\hline MFT & Melter Feed Tank \\
\hline PCCS & Product Composition Control System \\
\hline PCT & Product Consistency Test \\
\hline PS & Pour Stream \\
\hline RSD & Relative Standard Deviation \\
\hline SB & Sludge Batch \\
\hline SDF & Sludge Dilution Factor \\
\hline SEM & Scanning Electron Microscopy \\
\hline SME & Slurry Mix Evaporator \\
\hline SRAT & Sludge Receipt and Adjustment Tank \\
\hline SRNL & Savannah River National Laboratory \\
\hline TTQAP & Task Technical and Quality Assurance Plan \\
\hline TTR & Technical Task Request \\
\hline WAPS & Waste Acceptance Product Specifications \\
\hline wt $\%$ & Weight Percent \\
\hline
\end{tabular}




\subsection{Introduction}

The Defense Waste Processing Facility (DWPF) began processing Sludge Batch 4 (SB4), Macrobatch 5 (MB5) on May 29, 2007. Sludge Batch 4 was a blend of the heel of Tank 40 from Sludge Batch 3 (SB3) and SB4 as qualified in Tank $51^{1}$. On November 28, 2008, DWPF began processing Sludge Batch 5 (SB5) from Tank 40 which is a blend of the heel of Tank 40 from SB4, SB5 as qualified in Tank 51 and H-Canyon Pu and Np transfers. ${ }^{2}$ SB4 was processed using Frit $510^{3}$ and SB5 used Frit $418^{4}$.

The sludge is received into the DWPF Chemical Processing Cell (CPC) and is processed through the Sludge Receipt and Adjustment Tank (SRAT) and Slurry Mix Evaporator Tank (SME). The treated sludge slurry is then transferred to the Melter Feed Tank (MFT) and fed to the melter. During processing of each sludge batch, the DWPF is required to take at least one glass sample to meet the objectives of the Glass Product Control Program ${ }^{5}$ and to complete the necessary Production Records so that the final glass product may be disposed of at a Federal Repository.

The DWPF requested analysis of a radioactive glass sample obtained from the melter pour stream during processing of SB4 and SB5 ${ }^{6}$. Sample analysis followed the Task Technical and Quality Assurance Plan (TTQAP) ${ }^{7}$ as well as the Analytical Study Plan (ASP) ${ }^{8}$. Two Pour Stream (PS) glass samples were delivered to SRNL from the DWPF for both SB4 and SB5. Table 1-1 lists the sample information for each pour stream glass sample received from the DWPF. The glass samples from canisters S02905 and S03312 were visually inspected ${ }^{9}$ then archived in Cell 16 of the SRNL Shielded Cells according to procedure. ${ }^{10}$ This report details the visual observations of the as received glass samples as well as results for the Product Consistency Test (PCT) ${ }^{11}$, chemical composition, radionuclide content, noble metals, and glass density for the pour stream glass samples taken while filling canisters S02902 and S03317.

Table 1-1. DWPF Pour Stream Glass Sample Information.

\begin{tabular}{|c|c|c|c|c|c||}
\hline $\begin{array}{c}\text { Glass } \\
\text { Canister }\end{array}$ & $\begin{array}{c}\text { Primary } \\
\text { Canister }\end{array}$ & $\begin{array}{c}\text { Sludge } \\
\text { Batch }\end{array}$ & Sample Date & $\begin{array}{c}\text { SME } \\
\text { Batch }\end{array}$ & $\begin{array}{c}\text { Sample } \\
\text { Status }\end{array}$ \\
\hline \hline S02902 & PC0039 & 4 & March 16, 2008 & 435 & Analyzed \\
\hline S02905 & PC0042 & 4 & March 19, 2008 & 435 & Archived \\
\hline S03312 & PC0101 & 5 & March 15, 2010 & 520 & Archived \\
\hline S03317 & PC0102 & 5 & March 22, 2010 & 521 & Analyzed \\
\hline
\end{tabular}




\subsection{Experimental Procedure}

\subsection{Visual Examination, Extraction, and Washing}

The SB4 pour stream glasses arrived at SRNL on April 8, 2008. Both SB4 glass samples were inspected, weighed and archived. ${ }^{10}$ Upon receipt of the SB5 samples at SRNL on April 5, 2010, the SB4 pour stream sample designated for analysis was removed from archives. Both the SB4 and SB5 samples were removed from the Pt/Au collection samplers they arrived in, inspected, and washed according to procedure. ${ }^{12}$

\subsection{Chemical Composition}

The elemental composition of the glass was determined by dissolving samples of ground glass and analyzing the solutions by Inductively Coupled Plasma - (atomic) Emission Spectroscopy (ICP-ES). A sample of each pour stream glass was ground using the Mixer/Mill 5300 with a clean agate canister and two agate balls. A separate canister and balls were used for each pour stream glass to prevent any cross contamination. Quadruplicate samples of the SB4 and the SB5 glass were digested by two separate methods: mixed acid dissolution ${ }^{13}$ and sodium peroxide fusion. ${ }^{14}$ Three Analytical Reference Glass - $1^{15}$ (ARG-1) standards as well as a blank and multi-element standards were digested by each method and submitted with the pour stream glasses to Analytical Development (AD) for analysis.

\subsection{Radionuclide Composition}

The SB4 and SB5 pour stream glass samples digested using mixed acid dissolution were analyzed by Inductively Coupled Plasma - Mass Spectroscopy (ICP-MS) to determine the actinide and fission product content. The glass dissolved by peroxide fusion was analyzed by counting methods to calculate the radionuclide concentration in the pour stream glass samples. The reportable radionuclides for the Glass Product Control Program ${ }^{5}$ not measured in this study were calculated from the sludge slurry results ${ }^{1,2}$ using a calculated Sludge Dilution Factor (SDF) for each glass. $^{16}$

\subsection{Noble Metals}

The noble metal concentrations in the glass were analyzed using ICP-MS from the peroxide fusion dissolution. In addition, a sample of each glass was analyzed using Scanning Electron Microscopy (SEM) along with Energy Dispersive Spectroscopy (EDS) to image and analyze any inhomogeneities, including noble metal inclusions, in the glass. The glass samples used for SEM analysis were taken from the -200 mesh PCT fraction of glass.

\subsection{Product Consistency Test (PCT)}

The $\mathrm{PCT}^{11}$, a crushed glass leach test using ASTM Type I water, was performed on quadruplicate samples of both the SB4 glass and SB5 glass. The test, which was performed at $90{ }^{\circ} \mathrm{C}$ for seven days, included the appropriate blanks and triplicate samples of standard (Environmental Assessment (EA) glass and Approved Reference Material - 1 (ARM-1)) glasses as described in Test Method A of the PCT. The concentrations of B, Na, Li, Si, and U were measured in each glass sample leachate using ICP-ES. The $\mathrm{pH}$ of each leachate was also measured.

\subsection{Density}

The density of each pour stream glass was measured using a water displacement technique in the Shielded Cells. A piece of SB4 glass was placed in a graduated cylinder with confirmed volume markings. The mass of the glass was recorded and DI water was added incrementally to the graduated cylinder up to a known volume. The volume and mass of the water was recorded after 
each addition of water. The density of the glass was calculated from the mass of the water at known volumes. The graduated cylinder was dried and the procedure repeated for the SB5 glass sample.

\subsection{Results and Discussion}

\subsection{Visual Examination, Extraction, and Washing}

Figure 3-1 shows the as-received SB4 and SB5 pour stream glass samples. The SB4 glass was dark and shiny. The SB5 glass had an opaque film on top of dark shiny glass. Neither glass had any visual signs of crystallization. The SB5 glass was rinsed with DI water prior to removing it from the Pt foil. After rinsing and drying, the glass was black and shiny with no opaque film. Table 3-1 shows the results of the ICP-ES analysis of the rinse water, which indicate the film is primarily a $\mathrm{Na}_{2} \mathrm{SO}_{4}$ salt deposit which has been observed on previous DWPF glasses.
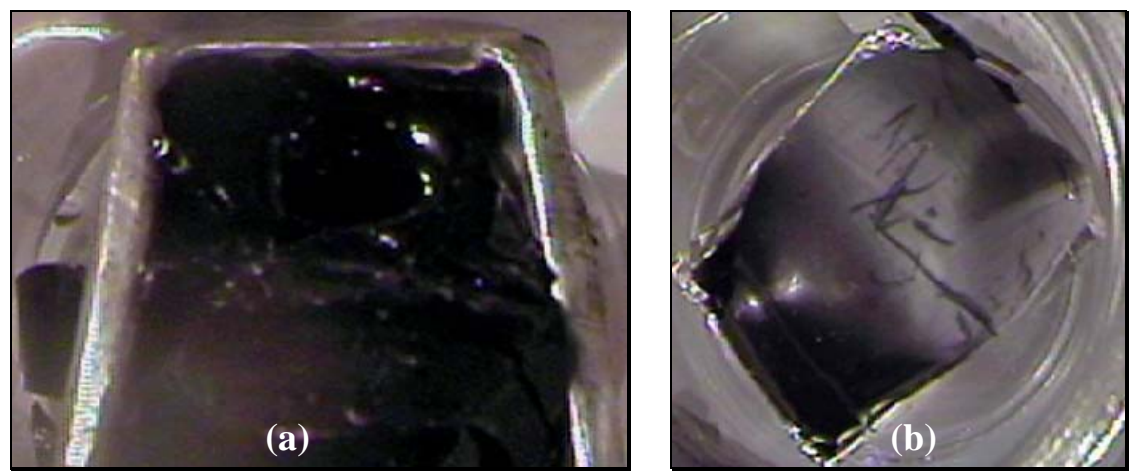

Figure 3-1. DWPF Pour Stream Glass Samples a) SB4 from Canister S02902 and b) SB5 from Canister S03317 As Received By SRNL.

Table 3-1. Analysis of Film on As Received SB5 Pour Stream Glass.

\begin{tabular}{|c|c|}
\hline Element & $\begin{array}{c}\text { Concentration } \\
\text { (mg/L) }\end{array}$ \\
\hline \hline $\mathrm{B}$ & 0.342 \\
\hline $\mathrm{Ba}$ & 0.774 \\
\hline $\mathrm{Ca}$ & 0.627 \\
\hline $\mathrm{Cd}$ & 0.641 \\
\hline $\mathrm{Cr}$ & 0.834 \\
\hline $\mathrm{Li}$ & 4.76 \\
\hline $\mathrm{Mg}$ & 0.0821 \\
\hline $\mathrm{Na}$ & 105 \\
\hline $\mathrm{S}$ & 75 \\
\hline $\mathrm{Zn}$ & 0.3 \\
\hline
\end{tabular}

Figure 3-1 also shows the Pt/Au collection samplers that were used to obtain each glass sample. The SB4 sample was collected using the Pt/Au metal crucible specifically fabricated for grabbing the glass pour stream sample. The SB4 sample was removed from the collection boat by using the stainless steel crushing device fabricated by DWPF. It took several blows from the crusher to remove the glass from the boat and as a result the glass was in several pieces. For SB5, the 
DWPF could not obtain the Pt/Au metal crucibles, so the sample was collected using a 3 mil platinum-gold foil cup. The SB5 sample was removed from the cup by peeling the foil off of the glass. The glass remained intact. It was subsequently crushed using the crushing device to obtain smaller glass pieces for analysis.

\subsection{Chemical Composition}

Table 3-2 shows the measured and published compositions for the standard ARG-1. Except where noted, the measured values are the average of triplicates of two digestion methods. Results indicate the glass was completely digested by the dissolutions since the chemical compositions are within the Product Composition Control System (PCCS) acceptance limits (95 $\leq$ sum of oxides $\leq 105)$. The analytical methods were performed according to procedure since the multielement standards submitted with the glass samples were within $10 \%$ of the standard values. ${ }^{9}$

The mixed acid dissolution method uses boric acid to complex the fluorine used to dissolve the glass; therefore, the boron content of the glass cannot be obtained by this method. Also, the silicon content cannot be determined since a quartz ICP torch is used and the hydrofluoric acid leaches silicon from the torch. ${ }^{13}$ The peroxide fusion method cannot be used to analyze zirconium, sodium or potassium since a zirconium crucible, sodium peroxide and potassium hydroxide are used in the dissolution.

Table 3-2. Measured and Published Values of Analytical Reference Glass - 1 (ARG-1).

\begin{tabular}{|c|c|c|c|c|}
\hline Oxide & $\begin{array}{c}\text { Measured } \\
\text { (Wt. \%) }\end{array}$ & $\begin{array}{l}\text { Published } \\
\text { (Wt. \%) }^{15}\end{array}$ & $\begin{array}{c}\text { Ratio } \\
\text { Measured/Published } \\
\end{array}$ & $\begin{array}{l}\text { Digestion } \\
\text { Method }^{\mathrm{a}} \\
\end{array}$ \\
\hline $\mathrm{Al}_{2} \mathrm{O}_{3}$ & 4.80 & 4.72 & 1.02 & $\mathrm{PF} / \mathrm{MA}$ \\
\hline $\mathrm{B}_{2} \mathrm{O}_{3}$ & 8.39 & 8.66 & 0.97 & $\mathrm{PF}$ \\
\hline $\mathrm{BaO}$ & 0.09 & 0.09 & 0.98 & $\mathrm{PF} / \mathrm{MA}$ \\
\hline $\mathrm{CaO}$ & 1.35 & 1.53 & 0.88 & MA \\
\hline $\mathrm{Cr}_{2} \mathrm{O}_{3}$ & 0.10 & 0.09 & 1.09 & $\mathrm{PF} / \mathrm{MA}$ \\
\hline $\mathrm{Fe}_{2} \mathrm{O}_{3}$ & 14.07 & 14.00 & 1.00 & $\mathrm{PF} / \mathrm{MA}$ \\
\hline $\mathrm{K}_{2} \mathrm{O}$ & 2.71 & 2.71 & 1.00 & MA \\
\hline $\mathrm{Li}_{2} \mathrm{O}$ & 3.16 & 3.21 & 0.98 & $\mathrm{PF} / \mathrm{MA}$ \\
\hline $\mathrm{MgO}$ & 0.86 & 0.86 & 1.00 & $\mathrm{PF} / \mathrm{MA}$ \\
\hline $\mathrm{MnO}$ & 1.87 & 1.88 & 0.99 & $\mathrm{PF} / \mathrm{MA}$ \\
\hline $\mathrm{Na}_{2} \mathrm{O}$ & 11.37 & 11.48 & 0.99 & MA \\
\hline $\mathrm{NiO}$ & 1.05 & 1.05 & 1.00 & $\mathrm{PF} / \mathrm{MA}$ \\
\hline $\mathrm{P}_{2} \mathrm{O}_{5}$ & 0.26 & 0.25 & 1.04 & MA \\
\hline $\mathrm{SiO}_{2}$ & 47.17 & 47.92 & 0.98 & $\mathrm{PF}$ \\
\hline $\mathrm{TiO}_{2}$ & 1.14 & 1.15 & 0.99 & $\mathrm{PF} / \mathrm{MA}$ \\
\hline $\mathrm{ZnO}$ & 0.02 & 0.02 & 1.09 & PF/MA \\
\hline $\mathrm{ZrO}_{2}$ & 0.13 & 0.13 & 1.01 & MA \\
\hline Total & 98.53 & 99.75 & -- & -- \\
\hline
\end{tabular}

${ }^{\mathrm{a}} \mathrm{PF}=$ Peroxide Fusion dissolution method, MA = Mixed Acid dissolution method

Table 3-3 and Table 3-4 list the oxide composition of SB4 and SB5 pour stream glasses, respectively. The average of the eight replicates (four from each dissolution method) was used unless otherwise noted. Some of the analytes were detected at values below the reporting limit of the instrument. For those analytes, the result is preceded by a "<" which indicates the result is an 
upper limit based on the sensitivity of the method. The Relative Standard Deviation (\%RSD) for the major glass components $(>0.5 \mathrm{wt} \%)$ is less than $5 \%$, indicating good precision in the results.

Table 3-3. Oxide Composition of SB4 Glass Pour Stream Sample (Canister S02902).

\begin{tabular}{|c|c|c|c|}
\hline Oxide & Wt \% & \%RSD & $\begin{array}{c}\text { Digestion } \\
\text { Method }^{\mathrm{a}}\end{array}$ \\
\hline $\mathrm{Ag}_{2} \mathrm{O}$ & $<<1.84 \mathrm{E}-02$ & N/A & $\mathrm{PF}$ \\
\hline $\mathrm{Al}_{2} \mathrm{O}_{3}$ & $7.78 \mathrm{E}+00$ & 3.07 & PF/MA \\
\hline $\mathrm{B}_{2} \mathrm{O}_{3}$ & $8.92 \mathrm{E}+00$ & 0.24 & PF \\
\hline $\mathrm{BaO}$ & $5.64 \mathrm{E}-02$ & 5.88 & $\mathrm{PF} / \mathrm{MA}$ \\
\hline $\mathrm{BeO}$ & $<1.51 \mathrm{E}-03$ & $\mathrm{~N} / \mathrm{A}$ & PF \\
\hline $\mathrm{CaO}$ & $7.16 \mathrm{E}-01$ & 4.54 & MA \\
\hline $\mathrm{CdO}$ & $5.85 \mathrm{E}-02$ & 4.06 & PF/MA \\
\hline $\mathrm{CeO}_{2}$ & $<1.60 \mathrm{E}-02$ & $\mathrm{~N} / \mathrm{A}$ & MA \\
\hline $\mathrm{Cr}_{2} \mathrm{O}_{3}$ & $5.84 \mathrm{E}-02$ & 3.10 & PF/MA \\
\hline $\mathrm{CuO}$ & $4.47 \mathrm{E}-02$ & 2.85 & PF/MA \\
\hline $\mathrm{Fe}_{2} \mathrm{O}_{3}$ & $8.21 \mathrm{E}+00$ & 3.56 & PF/MA \\
\hline $\mathrm{Gd}_{2} \mathrm{O}_{3}$ & 7.72E-03 & 8.84 & MA \\
\hline $\mathrm{K}_{2} \mathrm{O}$ & $7.91 \mathrm{E}-02$ & 7.45 & MA \\
\hline $\mathrm{La}_{2} \mathrm{O}_{3}$ & $1.20 \mathrm{E}-02$ & 10.8 & MA \\
\hline $\mathrm{Li}_{2} \mathrm{O}$ & $5.25 \mathrm{E}+00$ & 2.00 & $\mathrm{PF} / \mathrm{MA}$ \\
\hline $\mathrm{MgO}$ & $7.78 \mathrm{E}-01$ & 4.18 & PF/MA \\
\hline $\mathrm{MnO}$ & $1.62 \mathrm{E}+00$ & 4.12 & PF/MA \\
\hline $\mathrm{MoO}_{3}$ & $<7.31 \mathrm{E}-03$ & $\mathrm{~N} / \mathrm{A}$ & MA \\
\hline $\mathrm{Na}_{2} \mathrm{O}$ & $1.15 \mathrm{E}+01$ & 4.68 & MA \\
\hline $\mathrm{NiO}$ & 4.83E-01 & 5.21 & PF/MA \\
\hline $\mathrm{P}_{2} \mathrm{O}_{5}$ & $2.50 \mathrm{E}-01$ & 3.37 & MA \\
\hline $\mathrm{PbO}$ & $1.30 \mathrm{E}-02$ & 6.94 & MA \\
\hline $\mathrm{SO}_{4}$ & $3.57 \mathrm{E}-01$ & 4.36 & MA \\
\hline $\mathrm{Sb}_{2} \mathrm{O}_{5}$ & $<7.11 \mathrm{E}-02$ & $\mathrm{~N} / \mathrm{A}$ & MA \\
\hline $\mathrm{SiO}_{2}$ & $5.07 \mathrm{E}+01$ & 1.59 & $\mathrm{PF}$ \\
\hline $\mathrm{SnO}_{2}$ & $<1.27 \mathrm{E}-02$ & $\mathrm{~N} / \mathrm{A}$ & MA \\
\hline $\mathrm{SrO}$ & $1.25 \mathrm{E}-02$ & 4.30 & PF/MA \\
\hline $\mathrm{TiO}_{2}$ & $6.87 \mathrm{E}-02$ & 2.43 & PF/MA \\
\hline $\mathrm{U}_{3} \mathrm{O}_{8}$ & $2.23 \mathrm{E}+00$ & 4.75 & PF/MA \\
\hline $\mathrm{ZnO}$ & $3.04 \mathrm{E}-02$ & 10.1 & PF/MA \\
\hline $\mathrm{ZrO}_{2}$ & $1.65 \mathrm{E}-01$ & 4.69 & MA \\
\hline Sum & 99.44 & -- & -- \\
\hline
\end{tabular}

a. $\quad \mathrm{PF}=$ Peroxide Fusion dissolution method, $\mathrm{MA}=$ Mixed Acid dissolution method 
Table 3-4. Oxide Composition of SB5 Glass Pour Stream Sample (Canister S03317).

\begin{tabular}{|c|c|c|c|}
\hline Oxide & Wt \% & \%RSD & $\begin{array}{l}\text { Digestion } \\
\text { Method }^{\mathbf{a}}\end{array}$ \\
\hline $\mathrm{Ag}_{2} \mathrm{O}$ & $<1.80 \mathrm{E}-02$ & N/A & $\mathrm{PF}$ \\
\hline $\mathrm{Al}_{2} \mathrm{O}_{3}$ & $6.71 \mathrm{E}+00$ & 0.67 & PF/MA \\
\hline $\mathrm{B}_{2} \mathrm{O}_{3}$ & $5.58 \mathrm{E}+00$ & 0.31 & $\mathrm{PF}$ \\
\hline $\mathrm{BaO}$ & $3.67 \mathrm{E}-02$ & 1.14 & $\mathrm{PF} / \mathrm{MA}$ \\
\hline $\mathrm{BeO}$ & $<1.52 \mathrm{E}-02$ & $\mathrm{~N} / \mathrm{A}$ & $\mathrm{PF}$ \\
\hline $\mathrm{CaO}$ & $7.00 \mathrm{E}-01$ & 0.89 & MA \\
\hline $\mathrm{CdO}$ & $3.11 \mathrm{E}-02$ & 2.30 & $\mathrm{PF} / \mathrm{MA}$ \\
\hline $\mathrm{CeO}_{2}$ & $5.96 \mathrm{E}-02$ & 2.97 & MA \\
\hline $\mathrm{Cr}_{2} \mathrm{O}_{3}$ & $4.85 \mathrm{E}-02$ & 5.90 & PF/MA \\
\hline $\mathrm{CuO}$ & $1.76 \mathrm{E}-02$ & 7.47 & $\mathrm{PF} / \mathrm{MA}$ \\
\hline $\mathrm{Fe}_{2} \mathrm{O}_{3}$ & $8.53 \mathrm{E}+00$ & 0.40 & PF/MA \\
\hline $\mathrm{Gd}_{2} \mathrm{O}_{3}$ & $2.65 \mathrm{E}-02$ & 1.46 & MA \\
\hline $\mathrm{K}_{2} \mathrm{O}$ & $4.39 \mathrm{E}-02$ & 3.87 & MA \\
\hline $\mathrm{La}_{2} \mathrm{O}_{3}$ & $2.44 \mathrm{E}-02$ & 4.25 & MA \\
\hline $\mathrm{Li}_{2} \mathrm{O}$ & $5.55 \mathrm{E}+00$ & 0.89 & $\mathrm{PF} / \mathrm{MA}$ \\
\hline $\mathrm{MgO}$ & $5.06 \mathrm{E}-01$ & 0.99 & PF/MA \\
\hline $\mathrm{MnO}$ & $1.73 \mathrm{E}+00$ & 1.25 & PF/MA \\
\hline $\mathrm{MoO}_{3}$ & 7.94E-03 & 1.67 & MA \\
\hline $\mathrm{Na}_{2} \mathrm{O}$ & $1.34 \mathrm{E}+01$ & 0.48 & MA \\
\hline $\mathrm{NiO}$ & $9.62 \mathrm{E}-01$ & 1.60 & $\mathrm{PF} / \mathrm{MA}$ \\
\hline $\mathrm{P}_{2} \mathrm{O}_{5}$ & $2.14 \mathrm{E}-01$ & 0.90 & MA \\
\hline $\mathrm{PbO}$ & $1.27 \mathrm{E}-02$ & 6.70 & MA \\
\hline $\mathrm{SO}_{4}$ & $<2.35 \mathrm{E}-01$ & N/A & MA \\
\hline $\mathrm{Sb}_{2} \mathrm{O}_{5}$ & $<1.25 \mathrm{E}-02$ & $\mathrm{~N} / \mathrm{A}$ & MA \\
\hline $\mathrm{SiO}_{2}$ & $5.46 \mathrm{E}+01$ & 0.41 & $\mathrm{PF}$ \\
\hline $\mathrm{SnO}_{2}$ & $<9.95 \mathrm{E}-03$ & $\mathrm{~N} / \mathrm{A}$ & MA \\
\hline $\mathrm{SrO}$ & $1.84 \mathrm{E}-02$ & 1.74 & $\mathrm{PF} / \mathrm{MA}$ \\
\hline $\mathrm{TiO}_{2}$ & $1.97 \mathrm{E}-01$ & 0.61 & $\mathrm{PF} / \mathrm{MA}$ \\
\hline $\mathrm{U}_{3} \mathrm{O}_{8}$ & $2.22 \mathrm{E}+00$ & 2.58 & $\mathrm{PF} / \mathrm{MA}$ \\
\hline $\mathrm{ZnO}$ & $2.08 \mathrm{E}-02$ & 3.74 & PF/MA \\
\hline $\mathrm{ZrO}_{2}$ & $1.09 \mathrm{E}-01$ & 0.53 & MA \\
\hline Sum & 101.37 & -- & -- \\
\hline
\end{tabular}

a. $\quad \mathrm{PF}=$ Peroxide Fusion dissolution method, $\mathrm{MA}=$ Mixed Acid dissolution method

The calculated SDF of the pour stream glasses is the ratio of the concentration of aluminum, calcium, iron and manganese in the dried Tank 40 sludge to the concentration of the same elements in the pour stream glass sample. Table 3-5 and Table 3-6 show the calculation of the SDF for SB4 and SB5, respectively. These specific elements are used since they are only present in the sludge and not in the frit. ${ }^{16}$ The SDF will be used in Section 3.3 to calculate the concentration of radionuclides that were not directly measured in the glass. 
SRNL-STI-2010-00435

Revision 0

Table 3-5. Calculation of the Sludge Dilution Factor (SDF) for SB4 Pour Stream Glass.

\begin{tabular}{|c|c|c|c||}
\hline Element & SB4 Sludge & SB4 Glass & SDF \\
\hline $\mathrm{Al}$ & 9.52 & 4.12 & 2.31 \\
\hline $\mathrm{Ca}$ & 1.41 & 0.512 & 2.75 \\
\hline $\mathrm{Fe}$ & 14.3 & 5.74 & 2.49 \\
\hline $\mathrm{Mn}$ & 3.18 & 1.25 & 2.54 \\
\hline average & -- & -- & $\mathbf{2 . 5 2}$ \\
\hline
\end{tabular}

Table 3-6. Calculation of the Sludge Dilution Factor (SDF) for SB5 Pour Stream Glass.

\begin{tabular}{|c|c|c|c||}
\hline Element & SB5 Sludge & SB5 Glass & SDF \\
\hline \hline $\mathrm{Al}$ & 9.02 & 3.55 & 2.54 \\
\hline $\mathrm{Ca}$ & 1.38 & 0.5 & 2.76 \\
\hline $\mathrm{Fe}$ & 15 & 5.97 & 2.51 \\
\hline $\mathrm{Mn}$ & 3.48 & 1.34 & 2.60 \\
\hline average & -- & -- & $\mathbf{2 . 6 0}$ \\
\hline
\end{tabular}

\subsection{Radionuclide Composition}

Based on measurements and analytical detection limits, thirty-one radionuclides have been identified as reportable for DWPF SB4 (MB5) as specified by the Waste Acceptance Product Specification (WAPS) 1.2 and 1.6. ${ }^{1}$ In addition, twenty-eight reportable radionuclides have been identified for SB5. ${ }^{2}$ However, in an amendment to the Technical Task Request (TTR), five additional radionuclides in SB5 were requested to be analyzed for DWPF facility radiological engineering purposes, ${ }^{18}$ resulting in a total of thirty-three reportable radionuclides for SB5. Table 3-7 and Table 3-8 list the radionuclide content in the SB4 and SB5 pour stream glasses, respectively. Selected radionuclides were directly measured (in quadruplicate using gamma counting or ICP-MS) in the pour stream glasses and those results are documented in the fourth column of Table 3-7 and Table 3-8. Some of the radionuclides were detected at values below the reporting limit of the instrument. For those analytes, the result is preceded by a "<" which indicates the result is an upper limit based on the sensitivity of the method used to analyze that radionuclide. For those radionuclides not directly measured in the SB4 or SB5 glass, the radionuclide content was calculated from measured values from the dried sludge in Reference 1 (for SB4) and Reference 2 (for SB5) and the average SDF (Tables 3-4 and 3-5) for each pour stream glass. 
Table 3-7. Reportable Radionuclide Content of SB4 Pour Stream Glass.

\begin{tabular}{|c|c|c|c|}
\hline Radionuclide & $\begin{array}{c}\text { Tank 40 SB4 } \\
\text { Dried Sludge }^{\mathrm{a}} \\
\text { (Ci/kg) }\end{array}$ & $\begin{array}{c}\text { Calculated }^{\mathbf{b}} \\
\text { SB4 Glass } \\
\text { (Ci/kg) } \\
\end{array}$ & $\begin{array}{c}\text { Measured } \\
\text { SB4 Glass } \\
\text { (Ci/kg) } \\
\end{array}$ \\
\hline Nickel-59 $\left({ }^{59} \mathrm{Ni}\right)$ & $5.67 \mathrm{E}-04$ & $2.25 \mathrm{E}-04$ & +-- \\
\hline Nickel-63 $\left({ }^{63} \mathrm{Ni}\right)$ & $6.58 \mathrm{E}-02$ & $2.61 \mathrm{E}-02$ & -- \\
\hline Selenium-79 $\left({ }^{79} \mathrm{Se}\right)$ & $1.61 \mathrm{E}-05$ & $6.39 \mathrm{E}-06$ & -- \\
\hline Strontium-90 $\left({ }^{90} \mathrm{Sr}\right)$ & $7.23 \mathrm{E}+00$ & $2.87 \mathrm{E}+00$ & $2.85 \mathrm{E}+00^{\mathrm{c}}$ \\
\hline Zirconium-93 $\left({ }^{93} \mathrm{Zr}\right)$ & $2.64 \mathrm{E}-04$ & $1.05 \mathrm{E}-04$ & $1.76 \mathrm{E}-04^{\mathrm{d}}$ \\
\hline Niobium-93m $\left({ }^{93 m} \mathrm{Nb}\right)$ & $2.09 \mathrm{E}-04$ & $8.29 \mathrm{E}-05$ & -- \\
\hline Technetium-99 $\left({ }^{99} \mathrm{Tc}\right)$ & $1.41 \mathrm{E}-04$ & $5.60 \mathrm{E}-05$ & $<5.51 \mathrm{E}-05^{\mathrm{d}}$ \\
\hline Tin-126 $\left({ }^{126} \mathrm{Sn}\right)$ & $<3.24 \mathrm{E}-04$ & $<1.29 \mathrm{E}-04$ & -- \\
\hline Cesium-137 $\left({ }^{137} \mathrm{Cs}\right)$ & $2.49 \mathrm{E}-01$ & $9.88 \mathrm{E}-02$ & $1.03 \mathrm{E}-01^{\mathrm{c}}$ \\
\hline Samarium-151 ( $\left.{ }^{151} \mathrm{Sm}\right)$ & $1.13 \mathrm{E}-01$ & $4.48 \mathrm{E}-02$ & -- \\
\hline Uranium-233 $\left({ }^{233} \mathrm{U}\right)$ & $<1.91 \mathrm{E}-05$ & $<7.58 \mathrm{E}-06$ & $<2.36 \mathrm{E}-05^{\mathrm{d}}$ \\
\hline Uranium-234 $\left({ }^{234} \mathrm{U}\right)$ & $3.40 \mathrm{E}-05$ & $1.35 \mathrm{E}-05$ & $1.64 \mathrm{E}-05^{\mathrm{d}}$ \\
\hline Uranium-235 $\left({ }^{235} \mathrm{U}\right)$ & $6.41 \mathrm{E}-07$ & $2.54 \mathrm{E}-07$ & $2.41 \mathrm{E}-07^{\mathrm{d}}$ \\
\hline Uranium-236 $\left({ }^{236} \mathrm{U}\right)$ & $8.12 \mathrm{E}-07$ & $3.22 \mathrm{E}-07$ & $3.27 \mathrm{E}-07^{\mathrm{d}}$ \\
\hline Uranium-238 $\left({ }^{238} \mathrm{U}\right)$ & $1.77 \mathrm{E}-05$ & $7.02 \mathrm{E}-06$ & $6.36 \mathrm{E}-06^{\mathrm{d}}$ \\
\hline Neptunium-237 $\left({ }^{237} \mathrm{~Np}\right)$ & $2.60 \mathrm{E}-05$ & $1.03 \mathrm{E}-05$ & $9.33 \mathrm{E}-06^{\mathrm{d}}$ \\
\hline Plutonium-238 $\left({ }^{238} \mathrm{Pu}\right)$ & $1.22 \mathrm{E}-01$ & 4.84E-02 & $3.78 \mathrm{E}-02^{\mathrm{c}}$ \\
\hline Plutonium-239 $\left({ }^{239} \mathrm{Pu}\right)$ & $1.03 \mathrm{E}-02$ & $4.09 \mathrm{E}-03$ & $4.45 \mathrm{E}-03^{\mathrm{d}}$ \\
\hline Plutonium-240 $\left({ }^{240} \mathrm{Pu}\right)$ & $4.51 \mathrm{E}-03$ & $1.79 \mathrm{E}-03$ & $1.87 \mathrm{E}-03^{\mathrm{d}}$ \\
\hline Plutonium-241 $\left({ }^{241} \mathrm{Pu}\right)$ & $1.08 \mathrm{E}-01$ & 4.29E-02 & $<1.27 \mathrm{E}-02^{\mathrm{c}}$ \\
\hline Plutonium-242 $\left({ }^{242} \mathrm{Pu}\right)$ & 5.83E-06 & $2.31 \mathrm{E}-06$ & $<1.60 \mathrm{E}-05^{\mathrm{d}}$ \\
\hline Americium-241 $\left({ }^{241} \mathrm{Am}\right)$ & $1.76 \mathrm{E}-02$ & $6.98 \mathrm{E}-03$ & $7.66 \mathrm{E}-03^{\mathrm{c}}$ \\
\hline Americium-242m $\left({ }^{242 \mathrm{~m}} \mathrm{Am}\right)$ & $7.00 \mathrm{E}-05$ & $2.78 \mathrm{E}-05$ & -- \\
\hline Americium-243 $\left({ }^{243} \mathrm{Am}\right)$ & $1.64 \mathrm{E}-03$ & $6.51 \mathrm{E}-04$ & -- \\
\hline Curium-244 $\left({ }^{244} \mathrm{Cm}\right)$ & $9.07 \mathrm{E}-02$ & $3.60 \mathrm{E}-02$ & -- \\
\hline Curium-245 $\left({ }^{245} \mathrm{Cm}\right)$ & $<3.49 \mathrm{E}-05$ & $<1.38 \mathrm{E}-05$ & -- \\
\hline Curium-246 $\left({ }^{246} \mathrm{Cm}\right)$ & $1.90 \mathrm{E}-05$ & $7.54 \mathrm{E}-06$ & -- \\
\hline Curium-247 $\left({ }^{247} \mathrm{Cm}\right)$ & $<5.65 \mathrm{E}-06$ & $<2.24 \mathrm{E}-06$ & -- \\
\hline Curium-248 $\left({ }^{248} \mathrm{Cm}\right)$ & $<5.91 \mathrm{E}-06$ & $<2.35 \mathrm{E}-06$ & -- \\
\hline Berkelium-247 ( $\left.{ }^{247} \mathrm{Bk}\right)$ & $<1.36 \mathrm{E}-05$ & $<5.40 \mathrm{E}-06$ & -- \\
\hline Californium-251 $\left({ }^{251} \mathrm{Cf}\right)$ & $<1.88 \mathrm{E}-05$ & $<7.46 \mathrm{E}-06$ & -- \\
\hline
\end{tabular}

${ }^{\mathrm{a}}$ From SB4 WAPS (Reference 1)

${ }^{\mathrm{b}}$ Calculated from values in Reference 1 and the SDF in Table 3-5.

c Measured using gamma counting

d Measured using ICP-MS 
Table 3-8. Reportable Radionuclide Content of SB5 Pour Stream Glass.

\begin{tabular}{|c|c|c|c|}
\hline Radionuclide & $\begin{array}{c}\text { Tank } 40 \text { SB5 } \\
\text { Dried Sludge }^{\text {a }} \\
\text { (Ci/kg) }\end{array}$ & $\begin{array}{c}\text { Calculated }^{\mathbf{b}} \\
\text { SB5 Glass } \\
\text { (Ci/kg) } \\
\end{array}$ & $\begin{array}{c}\text { Measured } \\
\text { SB5 Glass } \\
\text { (Ci/kg) } \\
\end{array}$ \\
\hline Chlorine-36 $\left({ }^{36} \mathrm{Cl}\right)$ & $<9.75 \mathrm{E}-04$ & $<<3.75 \mathrm{E}-04$ & -- \\
\hline Nickel-59 $\left({ }^{59} \mathrm{Ni}\right)$ & $1.30 \mathrm{E}-03$ & $5.00 \mathrm{E}-04$ & -- \\
\hline Nickel-63 $\left({ }^{63} \mathrm{Ni}\right)$ & $1.11 \mathrm{E}-01$ & $4.27 \mathrm{E}-02$ & -- \\
\hline Strontium-90 $\left({ }^{90} \mathrm{Sr}\right)$ & $2.25 \mathrm{E}+01$ & $8.65 \mathrm{E}+00$ & $5.03 \mathrm{E}+00^{\mathrm{c}}$ \\
\hline Zirconium-93 $\left({ }^{93} \mathrm{Zr}\right)$ & $5.23 \mathrm{E}-04$ & $2.01 \mathrm{E}-04$ & $3.53 \mathrm{E}-04^{\mathrm{d}}$ \\
\hline Niobium-93m $\left({ }^{93 \mathrm{~m}} \mathrm{Nb}\right)$ & $3.93 \mathrm{E}-04$ & $1.51 \mathrm{E}-04$ & -- \\
\hline Technetium-99 $\left({ }^{99} \mathrm{Tc}\right)$ & $1.53 \mathrm{E}-04$ & $5.88 \mathrm{E}-05$ & $4.74 \mathrm{E}-05^{\mathrm{d}}$ \\
\hline Ruthenium-106 $\left({ }^{106} \mathrm{Ru}\right)$ & $<3.13 \mathrm{E}-04$ & $<1.20 \mathrm{E}-04$ & -- \\
\hline Rhodium-106 $\left({ }^{106} \mathrm{Rh}\right)$ & $<3.13 \mathrm{E}-04$ & $<1.20 \mathrm{E}-04$ & -- \\
\hline Tin-126 $\left({ }^{126} \mathrm{Sn}\right)$ & $<3.60 \mathrm{E}-04$ & $<1.38 \mathrm{E}-04$ & -- \\
\hline Cesium-134 $\left({ }^{134} \mathrm{Cs}\right)$ & $<8.86 \mathrm{E}-04$ & $<3.41 \mathrm{E}-04$ & -- \\
\hline Cesium-137 ( $\left.{ }^{137} \mathrm{Cs}\right)$ & $3.23 \mathrm{E}-01$ & $1.24 \mathrm{E}-01$ & $1.67 \mathrm{E}-01^{\mathrm{c}}$ \\
\hline Cerium-144 $\left({ }^{144} \mathrm{Ce}\right)$ & $<7.22 \mathrm{E}-04$ & $<2.78 \mathrm{E}-04$ & -- \\
\hline Promethium-147 $\left({ }^{147} \mathrm{Pm}\right)$ & $<7.22 \mathrm{E}-04$ & $<2.78 \mathrm{E}-04$ & -- \\
\hline Samarium-151 $\left({ }^{151} \mathrm{Sm}\right)$ & $1.82 \mathrm{E}-01$ & $7.00 \mathrm{E}-02$ & -- \\
\hline Uranium-233 $\left({ }^{233} \mathrm{U}\right)$ & $2.22 \mathrm{E}-05$ & $8.54 \mathrm{E}-06$ & $<1.56 \mathrm{E}-05^{\mathrm{d}}$ \\
\hline Uranium-234 $\left({ }^{234} \mathrm{U}\right)$ & $6.15 \mathrm{E}-05$ & $2.37 \mathrm{E}-05$ & $2.38 \mathrm{E}-05^{\mathrm{d}}$ \\
\hline Uranium-235 $\left({ }^{235} \mathrm{U}\right)$ & $7.00 \mathrm{E}-07$ & $2.69 \mathrm{E}-07$ & $2.79 \mathrm{E}-07^{\mathrm{d}}$ \\
\hline Uranium-236 $\left({ }^{236} \mathrm{U}\right)$ & $1.34 \mathrm{E}-06$ & $5.15 \mathrm{E}-07$ & $5.29 \mathrm{E}-07^{\mathrm{d}}$ \\
\hline Uranium-238 $\left({ }^{238} \mathrm{U}\right)$ & $1.67 \mathrm{E}-05$ & $6.42 \mathrm{E}-06$ & $6.37 \mathrm{E}-06^{\mathrm{d}}$ \\
\hline Neptunium-237 $\left({ }^{237} \mathrm{~Np}\right)$ & $6.92 \mathrm{E}-05$ & $2.66 \mathrm{E}-05$ & $1.91 \mathrm{E}-05^{\mathrm{d}}$ \\
\hline Plutonium-238 $\left({ }^{238} \mathrm{Pu}\right)$ & $2.76 \mathrm{E}-01$ & $1.06 \mathrm{E}-01$ & $1.66 \mathrm{E}-01^{\mathrm{c}}$ \\
\hline Plutonium-239 $\left({ }^{239} \mathrm{Pu}\right)$ & $2.04 \mathrm{E}-02$ & $7.85 \mathrm{E}-03$ & $6.69 \mathrm{E}-03^{\mathrm{d}}$ \\
\hline Plutonium-240 $\left({ }^{240} \mathrm{Pu}\right)$ & $6.59 \mathrm{E}-03$ & $2.53 \mathrm{E}-03$ & $2.06 \mathrm{E}-03^{\mathrm{d}}$ \\
\hline Plutonium-241 $\left({ }^{241} \mathrm{Pu}\right)$ & $9.74 \mathrm{E}-02$ & $3.75 \mathrm{E}-02$ & $3.49 \mathrm{E}-02^{\mathrm{c}}$ \\
\hline Plutonium-242 $\left({ }^{242} \mathrm{Pu}\right)$ & $6.82 \mathrm{E}-06$ & $2.62 \mathrm{E}-06$ & $<1.58 \mathrm{E}-05^{\mathrm{d}}$ \\
\hline Americium-241 $\left({ }^{241} \mathrm{Am}\right)$ & $3.25 \mathrm{E}-02$ & $1.25 \mathrm{E}-02$ & $1.06 \mathrm{E}-02^{\mathrm{c}}$ \\
\hline Americium-242m $\left({ }^{242 \mathrm{~m}} \mathrm{Am}\right)$ & $<4.54 \mathrm{E}-04$ & $<1.75 \mathrm{E}-04$ & -- \\
\hline Americium-243 $\left({ }^{243} \mathrm{Am}\right)$ & $9.64 \mathrm{E}-04$ & $3.71 \mathrm{E}-04$ & -- \\
\hline Curium-244 $\left({ }^{244} \mathrm{Cm}\right)$ & $4.61 \mathrm{E}-02$ & $1.77 \mathrm{E}-02$ & -- \\
\hline Curium-245 $\left({ }^{245} \mathrm{Cm}\right)$ & $<4.29 \mathrm{E}-04$ & $<1.65 \mathrm{E}-04$ & -- \\
\hline Curium-246 $\left({ }^{246} \mathrm{Cm}\right)$ & $1.29 \mathrm{E}-05$ & $4.96 \mathrm{E}-06$ & -- \\
\hline Californium-251 $\left({ }^{251} \mathrm{Cf}\right)$ & $<2.31 \mathrm{E}-05$ & $<8.88 \mathrm{E}-06$ & -- \\
\hline
\end{tabular}




\subsection{Noble Metals}

The concentrations of the noble metals in the SB4 and SB5 pour stream glasses are listed in Table 3-9 and Table 3-10 respectively. The measured concentrations were determined from the peroxide fusion dissolution ICP-MS data. The mixed acid dissolution does not fully dissolve the noble metals and therefore does not provide an accurate measurement of the concentrations of these elements in the glass. The calculated noble metal concentration in the glass is determined from the concentration in the sludge $\mathrm{e}^{19,20}$ and the SDF for each glass. The total silver concentration is the sum of isotopes ${ }^{107} \mathrm{Ag}$ and ${ }^{109} \mathrm{Ag}$. The palladium concentration is the sum of five isotopes: ${ }^{105} \mathrm{Pd},{ }^{106} \mathrm{Pd},{ }^{107} \mathrm{Pd},{ }^{108} \mathrm{Pd}$, and ${ }^{110} \mathrm{Pd}$. However, other isotopes are present at mass $106,107,108$, and 110 ; therefore, ${ }^{105} \mathrm{Pd}$ is the only palladium isotope that can be accurately measured in the glass. For both pour stream samples, ${ }^{105} \mathrm{Pd}$ was present at concentrations below the detection limit of the instrument. However, this limit corresponds to the calculated concentration in the glass, indicating the calculated Pd concentration in the glass is valid. The total concentration of ruthenium is the sum of the non-radioactive isotopes: ${ }^{101} \mathrm{Ru},{ }^{102} \mathrm{Ru}$, and ${ }^{104} \mathrm{Ru}$. The reported concentration of rhodium is from a single isotope, ${ }^{103} \mathrm{Rh}$. The measured noble metal content in the glass is higher than expected indicating that the noble metals are not accumulating in the melter.

Table 3-9. Noble Metal Concentration in the SB4 Glass Pour Stream Sample.

\begin{tabular}{|c|c|c|c|}
\hline Noble Metal & $\begin{array}{c}\text { Dried Sludge } \\
\text { (wt\%) }\end{array}$ & $\begin{array}{c}\text { Calculated SB4 } \\
\text { Glass (wt \%) }\end{array}$ & $\begin{array}{c}\text { Measured SB4 } \\
\text { Glass (wt \%) }\end{array}$ \\
\hline $\mathrm{Ag}$ & $2.92 \mathrm{E}-03$ & $1.16 \mathrm{E}-03$ & $1.86 \mathrm{E}-02$ \\
\hline $\mathrm{Pd}$ & $8.57 \mathrm{E}-04$ & $3.40 \mathrm{E}-04$ & $<1.00 \mathrm{E}-03$ \\
\hline $\mathrm{Rh}$ & $1.04 \mathrm{E}-02$ & $4.13 \mathrm{E}-03$ & $2.42 \mathrm{E}-03$ \\
\hline $\mathrm{Ru}$ & $4.27 \mathrm{E}-02$ & $1.69 \mathrm{E}-02$ & $7.22 \mathrm{E}-02$ \\
\hline
\end{tabular}

Table 3-10. Noble Metal Concentration in the SB5 Glass Pour Stream Sample.

\begin{tabular}{|c|c|c|c|}
\hline Noble Metal & $\begin{array}{c}\text { Dried Sludge } \\
\text { (wt\%) }\end{array}$ & $\begin{array}{c}\text { Calculated SB5 } \\
\text { Glass (wt\%) }\end{array}$ & $\begin{array}{c}\text { Measured SB5 } \\
\text { Glass (wt \%) }\end{array}$ \\
\hline $\mathrm{Ag}$ & $1.21 \mathrm{E}-02$ & $4.65 \mathrm{E}-03$ & $2.28 \mathrm{E}-02$ \\
\hline $\mathrm{Pd}$ & $3.21 \mathrm{E}-03$ & $1.23 \mathrm{E}-03$ & $<9.80 \mathrm{E}-04$ \\
\hline $\mathrm{Rh}$ & $2.01 \mathrm{E}-02$ & $7.73 \mathrm{E}-03$ & $5.67 \mathrm{E}-03$ \\
\hline $\mathrm{Ru}$ & $9.26 \mathrm{E}-02$ & $3.56 \mathrm{E}-02$ & $1.37 \mathrm{E}-01$ \\
\hline
\end{tabular}

In addition to ICP-MS, the glass was analyzed using SEM/EDS for noble metal inclusions. The images were taken using the Backscattered Electron (BSE) detector so that the heavy noble metal inclusions would be contrasted against the glass. Figure 3-2 shows an overall image of the SB4 glass. Examination of the glass shows bright, round spots on the glass which indicate the presence of noble metal inclusions. Figure 3-3 is a BSE image of the SB4 glass at higher magnification with the spots indicated where EDS analysis was performed. The EDS spectra for spots 5 and 6 are shown in Figure 3-4 and Figure 3-5, respectively. The EDS spectrum from spot 5 shows that the inclusions are primarily ruthenium, which corresponds to the glass analysis in Table 3-9. The presence of iron and manganese in the same spectrum indicates the spot size of the EDS is larger than the noble metal inclusion and it is picking up elements in the glass matrix. Other EDS spectra of similar inclusions showed the same results. Spot 6 (Figure 3-5) shows the expected EDS spectrum for the pour stream glass based on the compositional analysis in Section 3.2. 


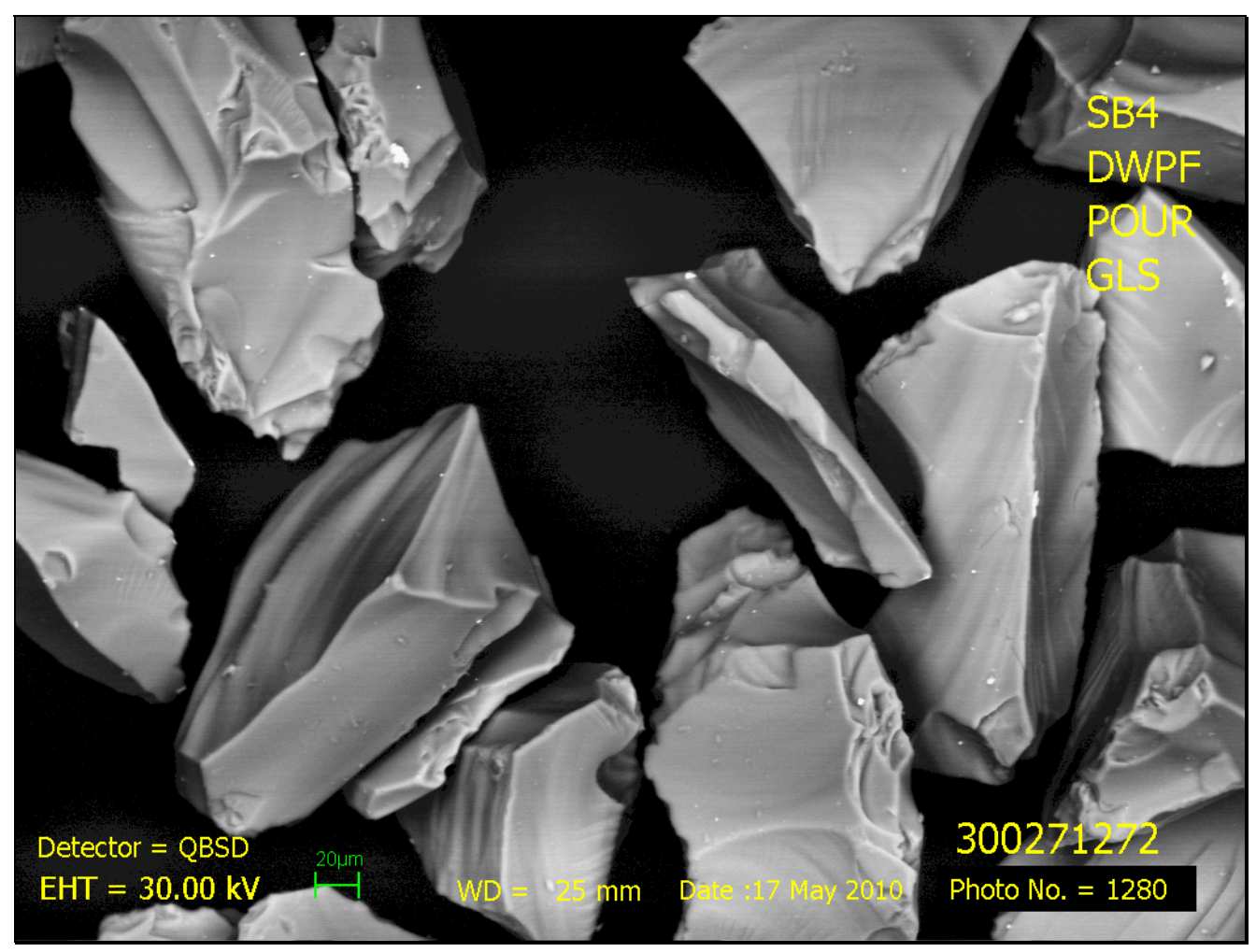

Figure 3-2. SEM BSE Image of SB4 Pour Stream Glass at 200x.

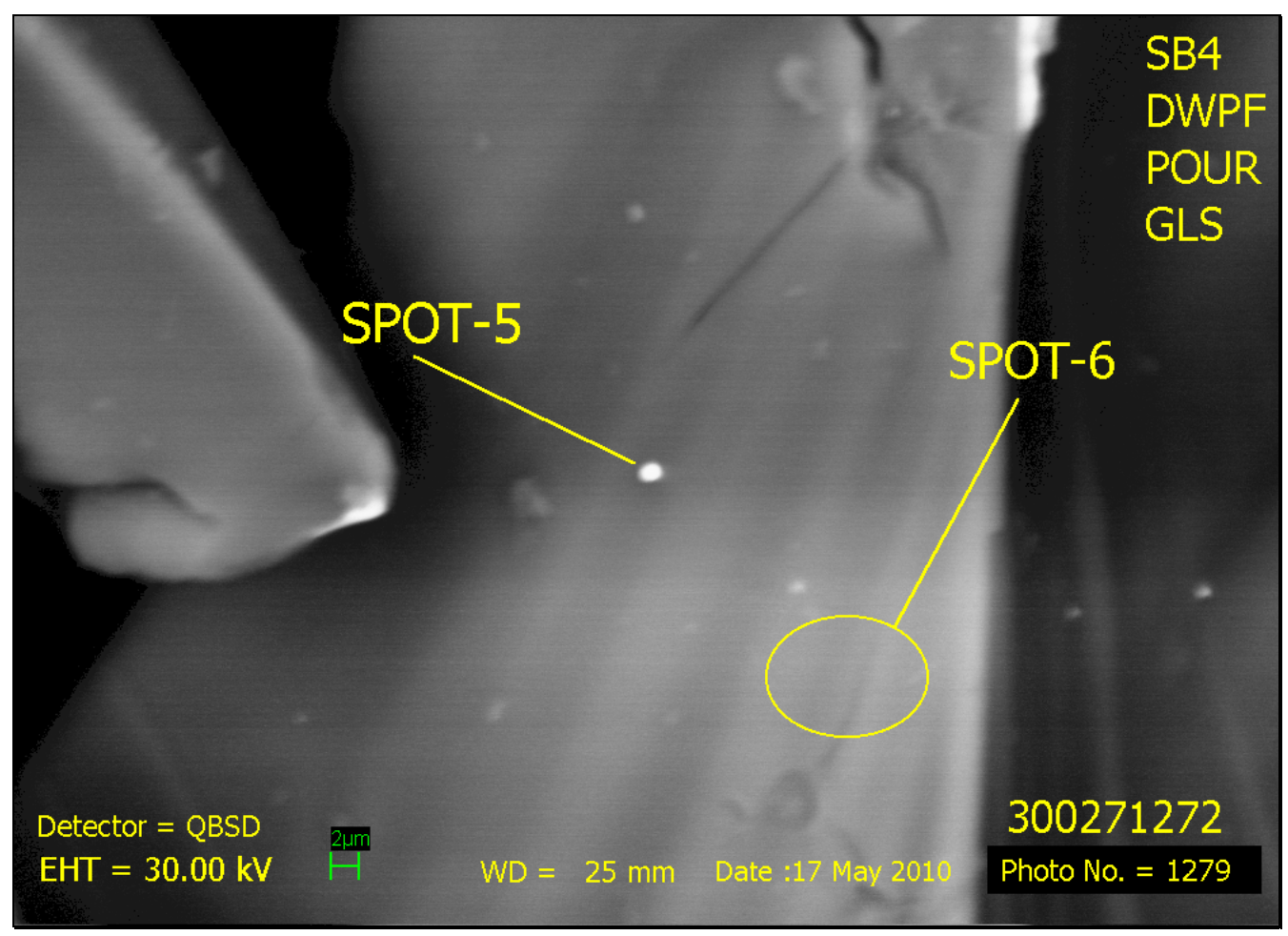

Figure 3-3. SEM Backscatter image of SB4 Pour Stream Glass at 1220x. 


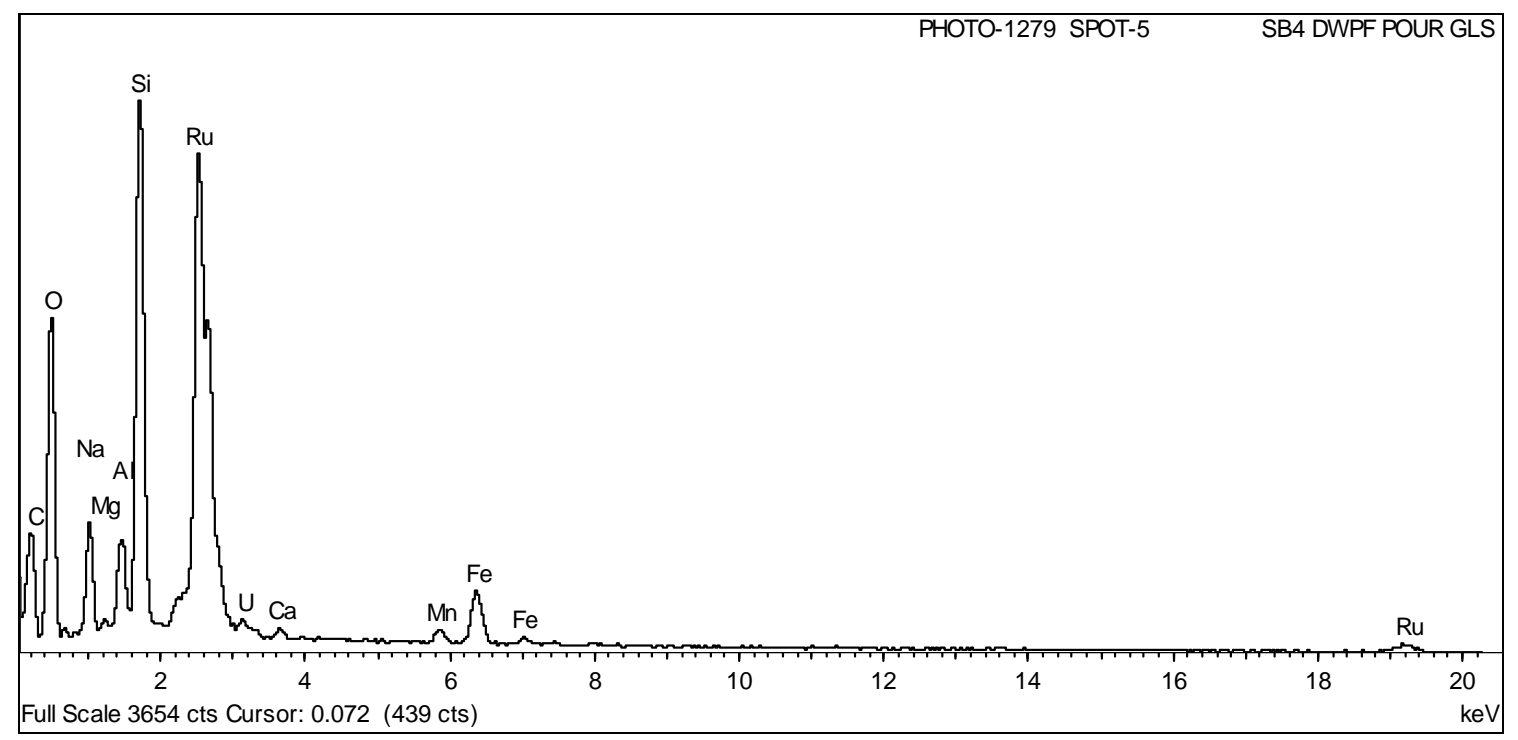

Figure 3-4. EDS Spectra of Spot 5 in Figure 3-3 for SB4 Pour Stream Glass, Indicating the Presence of Ru Noble Metal Inclusions.

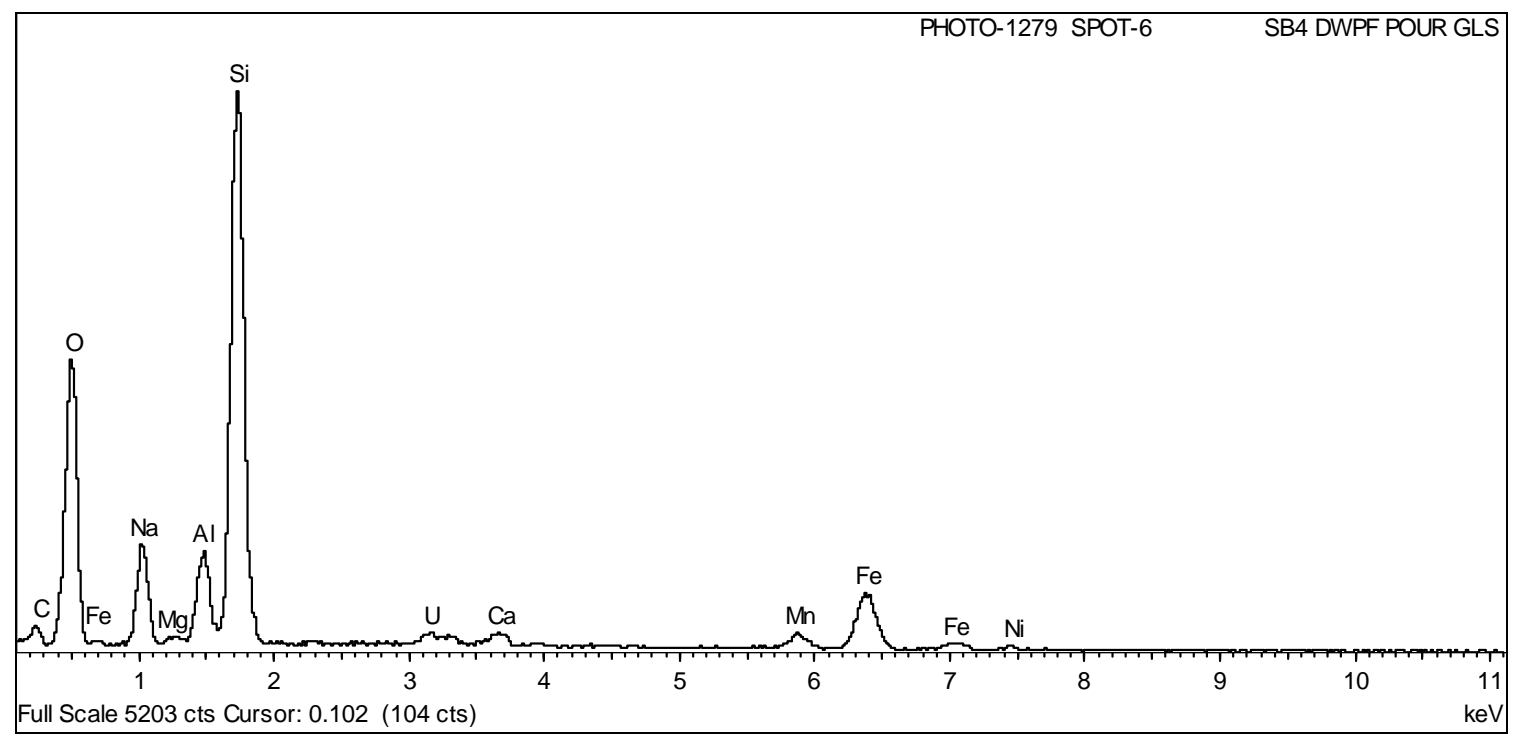

Figure 3-5. EDS Spectra of Spot 6 in Figure 3-3 for SB4 Pour Stream Glass. 
The SB5 pour stream glass sample was also analyzed using SEM/EDS. Figure 3-6 is a BSE image of several fractured glass pieces while Figure 3-7 is taken at a higher magnification to show the noble metal inclusions. The EDS spectra from spots 1, 2, and 3 in Figure 3-7 are shown in Figure 3-8, Figure 3-9, and Figure 3-10, respectively and are similar to the spectra from SB4 pour stream glass. Spots 1 and 3 (Figure 3-7) show the expected EDS spectrum based on the chemical composition of the glass. The artifacts on the surface of the larger fraction of glass analyzed by EDS as spot 1 are fines resulting from the grinding of the glass during preparations for the PCT. The EDS spectrum from spot 2 shows that the inclusions are primarily ruthenium, which corresponds to the noble metal analysis in Table 3-10.

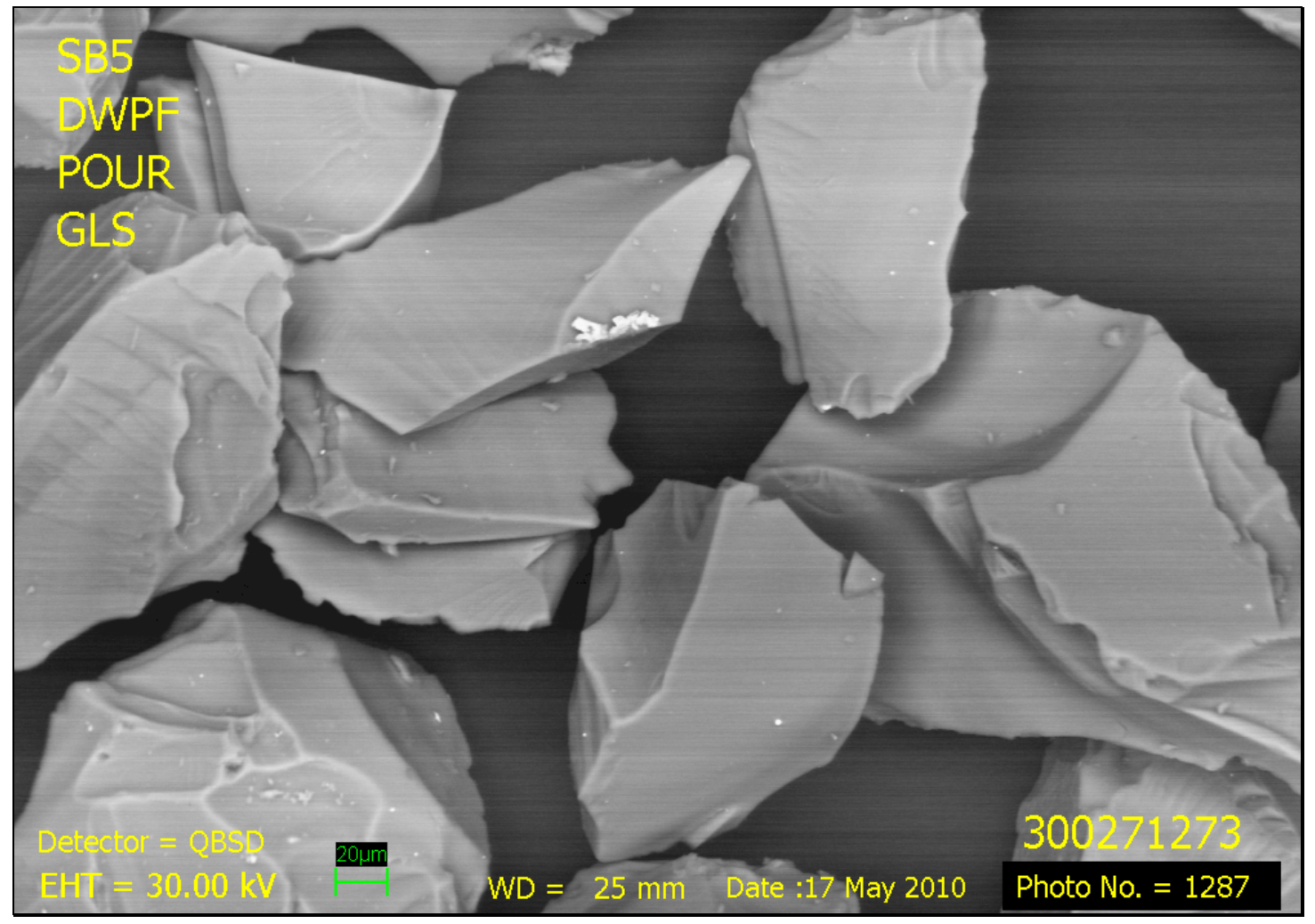

Figure 3-6. SEM BSE Image of SB5 Pour Stream Glass at 220x. 


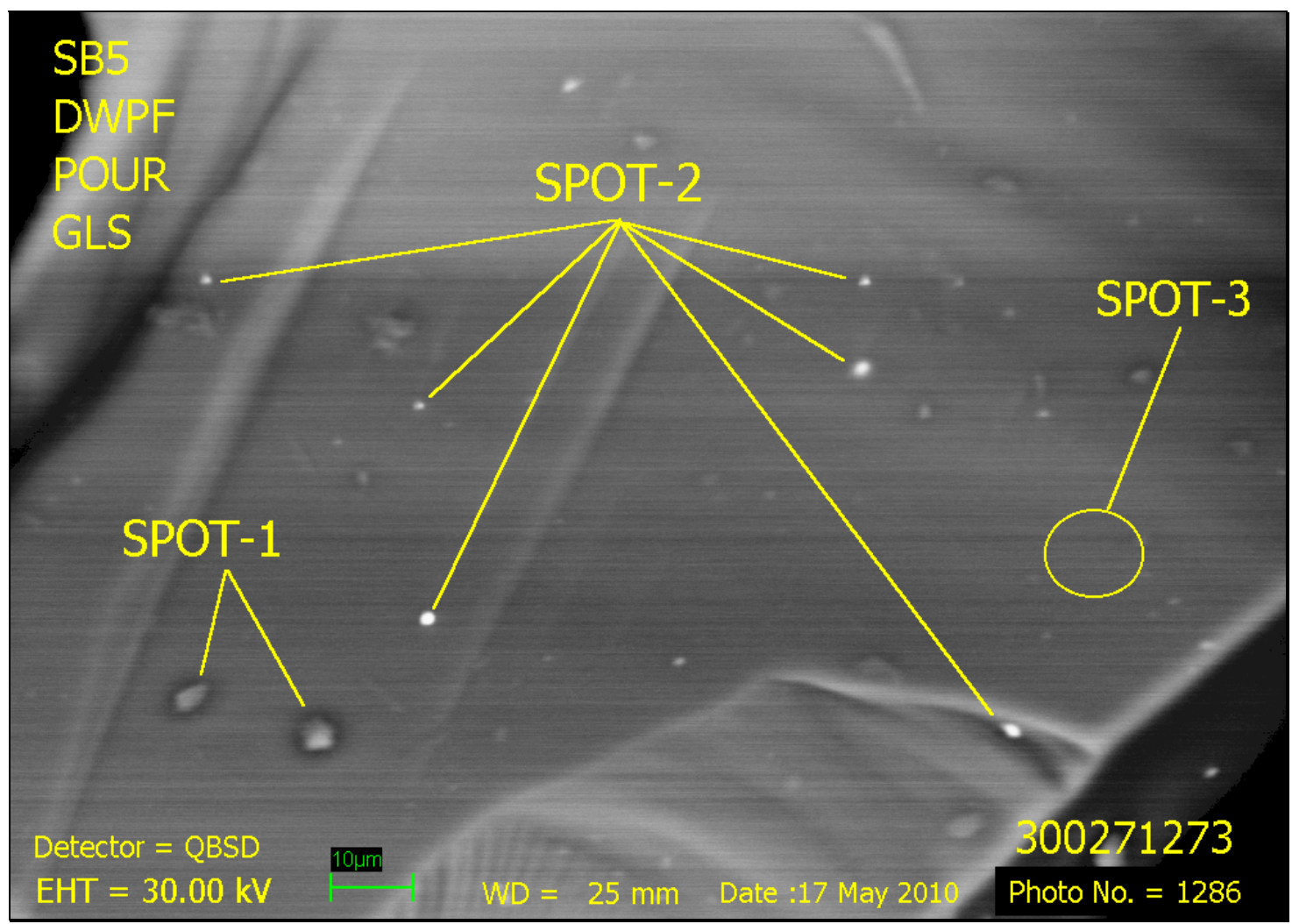

Figure 3-7. SEM BSE Image of SB5 Pour Stream Glass at 714x.

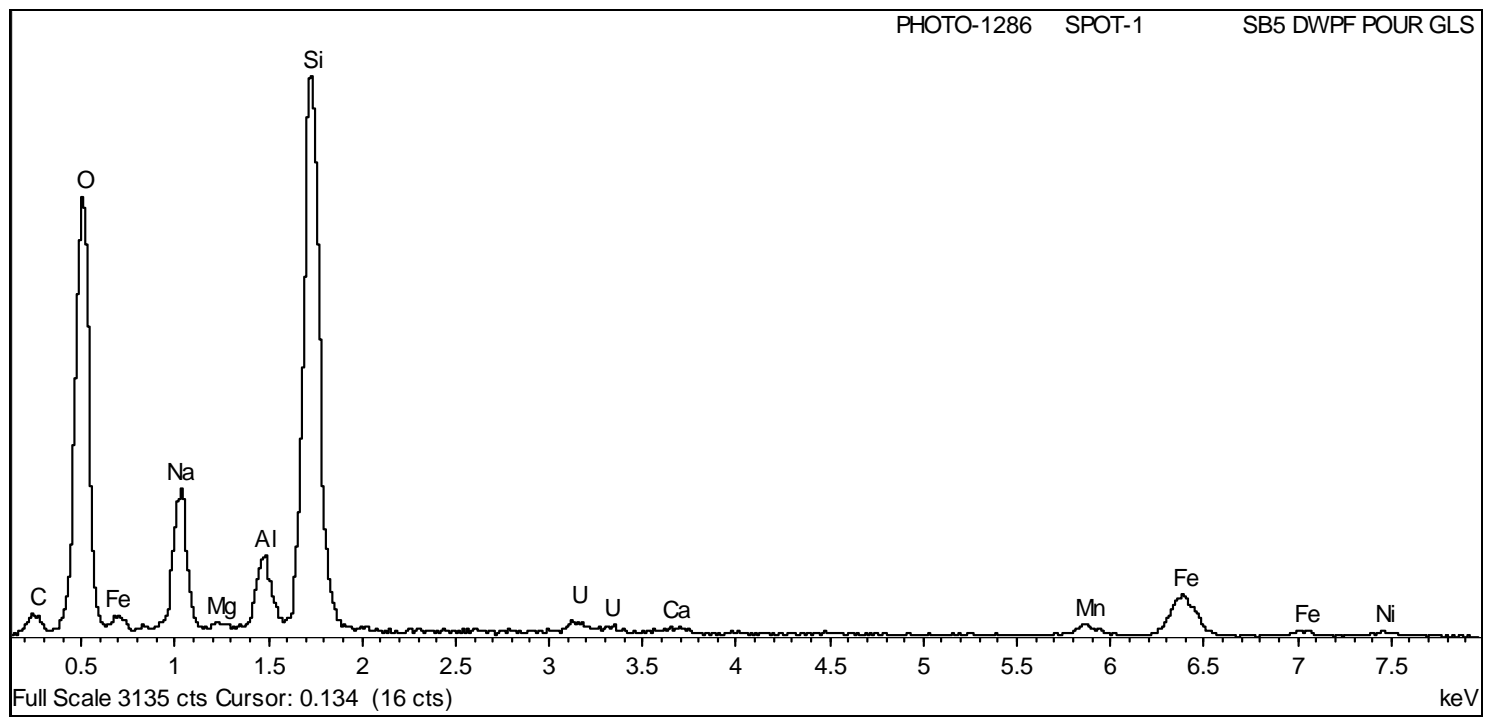

Figure 3-8. EDS Spectra of Spot 1 in Figure 3-7 for SB5 Pour Stream Glass. 




Figure 3-9. EDS Spectra of Spot 2 in Figure 3-7 for SB5 Pour Stream Glass Indicating the Presence of Ru Noble Metal Inclusions.

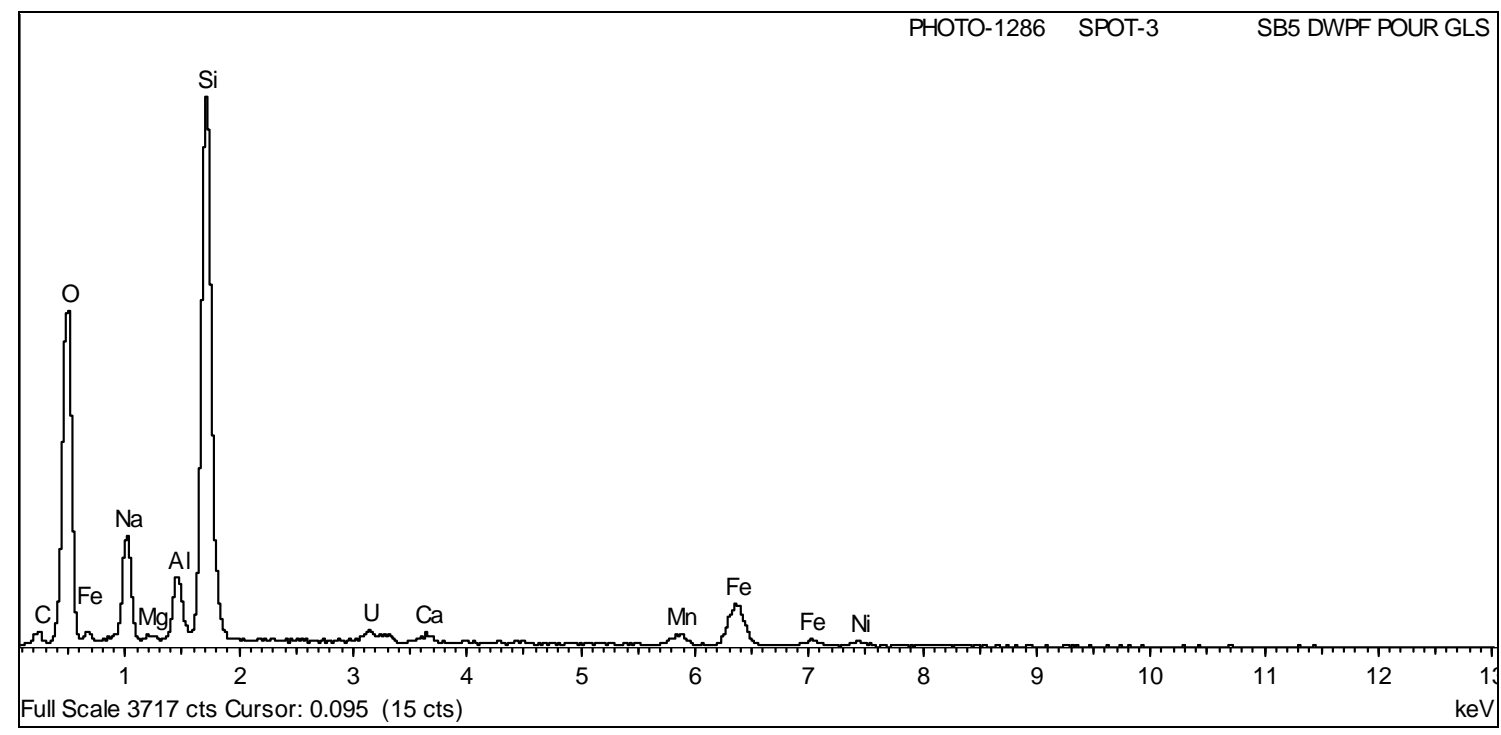

Figure 3-10. EDS Spectra of Spot 3 in Figure 3-7 for SB5 Pour Stream Glass. 


\subsection{Product Consistency Test (PCT)}

The average normalized release (grams of normalized element per liter of PCT leachate) for boron, sodium, lithium, silicon, and uranium as compared to the ARM and EA glasses as well as the average $\mathrm{pH}$ of the leachates are listed in Table 3-11. It should be noted that uranium is not required by the WAPS but is included to provide an indication of the radionuclide constituents in the leachate. The concentration of each element in the leachate as well as the measured chemical composition of the respective glass was used to calculate the average normalized release in terms of glass dissolved per liter of leachate. The published chemical composition of the ARM-1 and EA glasses were used to calculate the normalized release of those glasses. ${ }^{21,22}$

Table 3-11. Normalized PCT Results for SB4 and SB5 Pour Stream Glasses.

\begin{tabular}{||c|c|c|c|c||}
\hline Element & $\begin{array}{c}\text { SB4 } \\
\text { Dev, \%RSD) }\end{array}$ & $\begin{array}{c}\text { SB5 } \\
\text { Dev, \%RSD) }\end{array}$ & $\begin{array}{c}\text { Measured EA } \\
\text { (Std. Dev, \%RSD) }\end{array}$ & $\begin{array}{c}\text { Published EA }^{\mathbf{c}} \\
\text { (Std. } \\
\text { Dev, \%RSD) }\end{array}$ \\
\hline \hline $\mathrm{B}$ & $0.67(0.009,1.4)$ & $0.72(0.009,1.2)$ & $17.45(0.11,0.6)$ & $16.7(1.2,7)$ \\
\hline $\mathrm{Na}$ & $0.71(0.024,3.3)$ & $0.81(0.009,1.1)$ & $13.33(0.10,0.8)$ & $13.3(0.9,7)$ \\
\hline $\mathrm{Li}$ & $0.76(0.014,1.9)$ & $0.88(0.010,1.1)$ & $9.89(0.16,1.6)$ & $9.6(0.7,7)$ \\
\hline $\mathrm{Si}$ & $0.44(0.008,1.9)$ & $0.54(0.005,1.0)$ & $4.05(0.04,1.0)$ & $3.9(0.4,10)$ \\
\hline $\mathrm{U}$ & $0.29(0.009,3.0)$ & $0.38(0.011,3.0)$ & N/A & N/A \\
\hline $\mathrm{pH}$ & 10.92 & 11.25 & 11.96 & 11.9 \\
\hline
\end{tabular}

${ }^{a}$ Average of quadruplicate results

${ }^{\mathrm{b}}$ Average of triplicate results

${ }^{\mathrm{C}}$ Reference 22

The results for the ARM glass are within the acceptable ranges which indicate the PCT was performed under control. In addition, the vessels had minimal to no water loss during the test. ${ }^{9}$ The normalized elemental releases for $\mathrm{B}, \mathrm{Na}$, and Li reported in Table 3-11 for SB4 and SB5 pour stream glasses meet the acceptance criteria as defined in the WAPS. The criteria state the normalized release of boron, sodium, and lithium from the waste glass must be at least two standard deviations better than the EA glass. ${ }^{22}$

\subsection{Density}

Glass fractions weighing 2.0 and 2.4 grams were used to determine the density of the SB4 and SB5 pour stream glass samples, respectively. The measurements were performed in triplicate. The average density of the SB4 and SB5 pour stream glass were determined to be $2.50 \mathrm{~g} / \mathrm{cm}^{3}$ and $2.60 \mathrm{~g} / \mathrm{cm}^{3}$, respectively. 


\subsection{Conclusions}

- The sum of the oxides for the chemical composition of both the SB4 and SB5 pour stream glasses is within the Product Composition Control System (PCCS) acceptance limits $(95 \leq$ sum of oxides $\leq 105)$.

- The calculated Sludge Dilution Factor (SDF) for SB4 is 2.52. The measured radionuclide content is in good agreement with the calculated values from the dried sludge results from the SB4 Waste Acceptance Production Specification (WAPS) sample (References 1 and 19).

- The calculated SDF for SB5 is 2.60. The measured radionuclide content is in good agreement with the calculated values from the dried sludge results from the SB5 WAPS sample (References 2 and 20).

- Scanning Electron Microscopy (SEM) analysis shows there are noble metal inclusions, primarily ruthenium, present in both pour stream samples.

- The Product Consistency Test (PCT) results show that the SB4 pour stream glass meets the waste acceptance criteria for durability with a normalized boron release of $0.67 \mathrm{~g} / \mathrm{L}$ which is an order of magnitude lower than the Environmental Assessment (EA) glass.

- The PCT results show that the SB5 pour stream glass meets the waste acceptance criteria for durability with a normalized boron release of $0.72 \mathrm{~g} /$ which is an order of magnitude lower than the EA glass.

- The density of the SB4 glass is $2.5 \mathrm{~g} / \mathrm{cm}^{3}$.

- The density of the SB5 glass is $2.6 \mathrm{~g} / \mathrm{cm}^{3}$. 


\subsection{References}

1. Bannochie, C.J., Bibler, N.E., and DiPrete, D.P., "Determination of Reportable Radionuclides for DWPF Sludge Batch 4 (Macrobatch 5)," Savannah River National Laboratory, WSRC-STI-2008-00142, Rev. 0, May 2008.

2. Bannochie, C.J., Bibler, N.E., and DiPrete, D.P., "Determination of Reportable Radionuclides for DWPF Sludge Batch 5 (Macrobatch 6)," Savannah River National Laboratory, SRNL-STI-2009-00821, Feb 2010.

3. Peeler, D.K., Edwards, T.B., and Fox, K.M., "Delaying the SB4 Transfer: An Assessment of the Impact on the Frit Recommendation and the Variability Study," Savannah River National Laboratory, SRNL-PSE-2007-00066, March 20, 2007.

4. Fox, K.M., Edwards, T.B., and Peeler, D.K., "Recommended Frit Composition for Initial Sludge Batch 5 Processing at the Defense Waste Processing Facility," Savannah River National Laboratory, WSRC-STI-2008-00338, Rev. 0, June 2008.

5. Ray, J.W., Staub, A.V., Plodinec, M.J., and Marra, S.L., "DWPF Glass Product Control Program," Savannah River National Laboratory, Aiken, SC, WSRC-IM-91-116-6, Rev. 5, 2004.

6. Ray, J.W., "Analysis of Sludge Batch 4 and 5 Pour Stream Glass Samples," DWPF, Aiken, SC, Technical Task Request, HLW-DWPF-TTR-2009-0007, 2009.

7. Billings, A.L. and Bannochie, C.J., "Analysis of Sludge Batch 4 and 5 Pour Stream Glass Samples: Task Technical \& Quality Assurance Plan," Savannah River National Laboratory, Aiken, SC, SRNL-RP-2009-00283, 2009.

8. Billings, A.L. and Bannochie, C.J., "Analysis of Sludge Batch 4 and 5 DWPF Pour Stream Glass Samples: Analytical Study Plan," Savannah River National Laboratory, SRNL-RP-2009-00874, 2009.

9. $\quad$ "SB4 Pour Stream Samples," Savannah River National Laboratory, WSRC-NB-200800043, April 1, 2008.

10. "Archiving DWPF Pour Stream Samples," Savannah River National Laboratory, Procedure No. TC-90-026, Rev. 3, February 2008.

11. Standard Test Methods for Determining Chemical Durability of Nuclear, Hazardous, and Mixed Waste Glasses and Multiphase Glass Ceramics: The Product Consistency Test (PCT). ASTM C 1285-02, 2008.

12. Bannochie, C.J. and Bibler, N.E., "Current and New Controls in the Shielded Cells for Handling DWPF Pour Stream Glasses and Comments Concerning S02244 and S02247 Glasses," Savannah River National Laboratory, SRNL-ITS-2005-00127, May 2005.

13. "Acid Dissolution of Glass and Sludge for Elemental Analysis," Savannah River National Laboratory, Manual L16.1, SRNL-ADS-Procedure 2227, Rev. 8, 2007. 
14. "Alkali Fusion Dissolutions of Sludge and Glass for Elemental and Anion Analysis," Savannah River National Laboratory, Manual L16.1, SRNL-ADS-Procedure 2502, Rev. 6,2008 .

15. Smith, G.L., "Characterization of Analytical Reference Glass-1 (ARG-1)," Pacific Northwest National Laboratory, Richland, WA, PNL-8992, 1993.

16. Ray, J.W., Culbertson, B.H., Edwards, T.B., Bibler, N.E., and Marra, S.L., "Reporting the Radionuclide Inventory of the DWPF Product (U)," Savannah River Site, WSRC-IM91-116-4, Rev. 4, June 2007.

17. Standard Test Methods for Specific Gravity of Soil Solids by Water Pycnometer, ASTM Standard D 854-06, 2006.

18. Bannochie, C.J., "Additional Radionuclides from Sludge Batch 5 (SB5) Waste Acceptance Product Specifications (WAPS)," Savannah River National Laboratory, SRNL-L3100-2010-00035, February 10, 2010.

19. Bannochie, C.J., "Tank 40 Final SB4 Chemical Characterization Results," Savannah River National Laboratory, WSRC-STI-2007-00674, January 2008.

20. Bannochie, C.J. and Click, D.R., "Tank 40 Final SB5 Chemical Characterization Results Prior to Np Addition," Savannah River National Laboratory, SRNL-STI-2009-00060, Rev. 2, January 2010.

21. Jantzen, C.M., Pickett, J.B., Brown, K.G., Edwards, T.B., and Beam, D.C., "Process/Product Models for the Defense Waste Processing Facility (DWPF): Part I. Predicting Glass Durability From Composition Using Thermodynamic Hydration Energy Reaction Model (THERMO)," Savannah River Site, WSRC-TR-93-672, Rev. 1, 1995.

22. Jantzen, C.M., Bibler, N.E., Beam, D.C., Crawford, C.L., and Pickett, M.A., "Characterization of the Defense Waste Processing Facility (DWPF) Environmental Assessment (EA) Glass Standard Reference Material," Savannah River Site, WSRC-TR92-346, 1994. 